\title{
Albania in the European Perspective. The Fulfillment of the Copenhagen Criteria, A Necessary Condition Towards the EU
}

\author{
Alketa Serjanaj, PhD Candidate \\ Teacher at high school "Halim Xhelo" Vlore \\ alketaserjanaj@yahoo.com
}

\author{
Doi:10.5901/ajis.2014.v3n4p33
}

Abstract

The concretization of the European perspectives for the Western Balkans presented at the high level meeting in Thessaloniki in 2003, known as the Thessaloniki Agenda, is the cornerstone of the EU policy for the Western Balkans region and the fulfillment of the Copenhagen criteria is essential for the EU membership application. Since 2003, The European Commission checks the fulfilling of these criteria by the means of so-called progress reports. Based on a 10 -year reporting period by the European Commission to Albania, I have focused on the performance of the political criteria for highlighting not only the chronological developments in every field with the highlighted achievements and problems, but also to analyze the tasks that the EU has left each year and the role that Albanian political factor has played in the meeting of this criteria.

Keywords: EU; Albania; progress report ; the political criterion ; integration;

\section{Introduction}

The year of 1991 marked for Albania establishing diplomatic relations with the EU and a year later in May 11, 1992 these relationships materialized with the signing of Trade And Cooperation Agreement which allowed Albania to benefit from program funds PHARE . In the framework of this program, during the period 1992-2002 Albania received a considerable amount of funds. In 1999 , Albania became part of the Stabilization and Association process since the launch of that initiative. While in 2000 , Albania received the status of a potential candidate for integration into the EU after the European Council meeting in Feira.

In January 2003 the European Commission formally opened negotiations for a Stabilization and Association Agreement between Albania and the EU .

On 12 June 2006 , Albania became the third country in the region that signed its Stabilization and Association Agreement between the European Community and its Member States. This agreement entered into force on 1st April 2009 and within that month Albania also requested to be a member of the EU. In front of the European perspective, Albania must fulfill a number of obligations that have to do with the Copenhagen criteria. ${ }^{1}$

But what rout has pursued Albania in meeting the political criteria?

\section{Parliament Issues in 10 Years of Reporting of the EU from 2003 to 2013.}

The functioning of the parliament in a ten-year period will follow this sequential: The parliament of 2003 will be characterized by a growing dialogue between political parties and this will conclude the creation of some of parliamentary committees on issues such as:

1 - elections 2 - property restitution 3 - integration ${ }^{2}$

but the 2004 parliament will be involved by a opposition boycott as a result of the objection of local elections. However, when it comes to a session devoted to the SAA report in 2003 the parliament will play its role. 2005 marks for Albania's parliamentary elections which will be evaluated by the OSBE_ODIHR as a soft transition of power, but which would bring with it problems like excessive length of the process, low representation of women in parliament and

\footnotetext{
${ }^{1}$ www.mie.gov.al

${ }^{2}$ ec.europa.eu/enlargement.al/rapport_2003
} 
problems with the lists of voters. ${ }^{3}$ Parliamentary work in 2005 would bring approval of the law on restitution and property compensation, several amendments to the electoral code and a set of laws against organized crime. Progress will be shown on the establishment of a Permanent Commission For European Integration, even though the political climate will result in slowing of some key initiatives. This political deadlock will culminate in the summer of 2006 with the obstruction of parliamentary work for the electoral reform, continuously a key recommendation from the OSBE_ODIHR. It would be needed the intervention of the international factor to resolve this political situation. 2006 will be efficient in terms of relations between parliament, the president and the Constitutional Court. Active will also be the Integration Committee, but for it the year of 2007 will mark a step back because of not having regular meetings, it has hindered the progress of reforms on SAP. Although this year, the Parliament will raise the ad-hoc committee on electoral reform, a recommendation by the OSBE ODIHR, the lack of political will, will not mark progress in this matter. This year marks a slowdown of the electoral reforms in justice. A turning point will be 2008 regarding the commencement of cooperation in major issues such as electoral and judicial reform, and for the latter was also set up ad-hoc committee. Although the presidential election in 2007 with a three-fifths ${ }^{4}$ will pass the test, in 2008 will happen the first clashes between the president and the parliament institution in the appointment of judges. The progress this year affected the lists of voters with the electronic civil registry and address system. The end of 2008 will mark approval for the Albanian parliament election code which will be evaluated as a fulfillment by OSBE ODIHR.

The electoral code would affect the 28 June 2009 elections that would meet the legal commitments as voter lists. ${ }^{5}$ But on the other hand the electoral code would worsen the dialogue between political parties, which although the intervention of the international factor it will not solve the political impasse that lasted more than a year and seriously impeded the adoption of electoral reforms. A novelty in 2009 would be the publication of the parliamentary committee sessions which means parliamentary transparency. This transparency will increase in $2010^{6}$ by hearing of the public and online broadcasting in 2011 of the parliamentary sessions. But the events of 21 January 2011 and the prolonged process of Tirana mayoral race in the 2011, local elections will reinstate another political deadlock in parliamentary life that will last for 8 months in 2011. What does this mean for the parliamentary life?

1. disapproval of laws that want two thirds of the votes

2. electoral reform locking

but as a result of a political agreement at the end of $2011^{7}$, the parliament in 2012 made significant progress and it will bring adopting laws requiring considerable majority to approve changes of the electoral code. The year of 2013 will result in a positive evaluation and approval of Civil Service Law and the Law for the Supreme Court Albanian parliament once again will strengthen the work of his main priority, European integration.

\section{Public Administration Issues. 2013, Adoption of Civil Service Law}

One of the key priorities is the public administration reform. It would take 10 full years that the key priority of the Civil Service Law approved in May $2013^{8}$, which means a big step towards de-politicization of public administration. The negative assessment of 10 years, certainly addresses to the Albanian political class and this also relates to the fact that many have seen necessary support by administration that reaches a significant number of 90 thousand people.

But what were the rights and how has the civil service law operated?

Politicized public administration is a term that will characterize European assessment from 2003 onwards. But during these 10 years some steps towards reform have been done. 2004 will mark progress in public administration reform with the adoption of the law on the control of the assets of officials and increased training of civilian employees, a training that will continue in 2005. But this year certain amendments concerning with common principles to all civil servants will be approved. The politicization of public administration emphasized further with the change of government in 2006 . 2007 will mark a achievement to be taken into consideration, the space for graduate students abroad who would have priority in the public administration that will continue in 2008. This year will also bring some changes in the law of Performance Evaluations Of Civilian Employees that will follow in 2009 with the adoption of the strategy of the reform of

\footnotetext{
${ }^{3}$ ec.europa.eu/enlargement.al/rapport_2005

${ }^{4}$ ec.europa.eu/enlargement.al/rapport_2007

${ }^{5}$ ec.europa.eu/enlargement.al/rapport_2009

${ }^{6}$ ec.europa.eu/enlargement.al/rapport_2010

${ }^{7}$ ec.europa.eu/enlargement.al/rapport_2011

${ }^{8}$ ec.europa.eu/enlargement.al/rapport_2013
} 
public administration that provided a review of the Civil Service Law9. A disturbing problem will be the under contract employees, who reach $20 \%$ and this obviously creates scope for politicization of the administration. This problem will be resolved with a government decision in 2010 to limit the under contract employees ${ }^{10}$. The year 2011 will be summarized by the definition of "limited progress" and here it is noticed a lack of the political factor when it comes to adopting laws such as the law on general administrative procedures, the law on the functioning of public administration, law on administrative courts which require a qualified majority of 3/5 for approval. 2013 will bring overthrow of negative votes where the adoption of Civil Service Law will lead to the improvement of administrative reform as a prioritizing key. Implementation of this law is another defining challenge for this priority.

\section{Judicial System Issues}

Albanian judicial system is based on the Constitution of 1998 where is foreseen in the respective legislation even the principle of Independence. In a period of 10 years, many actions have been taken concerning the reform of the judiciary, but it has always been characterized problematic by the European Commission regarding to:

1 - Transparency 2 -Independence 3- Efficiency.

Following the developments within the system in a chronological order, I can say that the problems are multiple in this strong pillar of liberal democracy system. The low rating by the EU commission for the judiciary in 2003 was based on a simple fact: from 15,444 stored decisions, only 4,200 were executed. ${ }^{11}$ This alarming figure would make the commission to leave as primary task the execution of these decisions until 2005. 2003 will bring a change in criminal procedure aimed at fighting corruption. Although some small improvements regarding wages system, ratifying several international conventions, some progress in the execution of court decisions and court raising serious crimes, this system still remains weak in 2004. Emphasis will be placed on the extensive corruption of this system, which was also a conclusion of eastern European Initiative for Legal Development. Some progress will be marked in 2005 as regards of the organization $\mathrm{HCJ}$ (High Council of Justice), the training of judges and adoption of anti-mafia package that presented new legal tools to facilitate the capture of financial crime. But a problem is the legislation with no clear separation of powers between the ministry and $\mathrm{HCJ}$ because Albania's justice minister stands upon the $\mathrm{HCJ}$. Although in $2006^{12}$ the Constitutional Court will underline the strength of independence of the judiciary system, and the council of ministers will approve a new law regulating the organization of it, this sector will be characterized by prolonged proceedings, with poor organization and the lack of transparency even in 2007. Precisely in this year the government measures to combat corruption in the judiciary, would lead to a collision of two important institutions: the executive and the general Prosecutor.

2008 will bring a national pact in the field of justice which will be supported by the parties. This progress would be achieved in this year with the adoption of the law on the organization of the judiciary which defines the categories of merit based wages. Also, the law will be approved for private bailiff alongside private and this means help in the execution of the decisions of the courts. However Independence and Efficiency remain unmet priorities that would accompany 2009, where still exist unresolved overlapping powers between the $\mathrm{HJC}$ and the Ministry of Justice. Some progress is made in the judicial infrastructure with the installation of a computer system and randomly assigning judicial cases. But Albania's real problems are related to the legal framework and a reformation of the judicial system. The year 2010 will delegate ongoing problems, by the commission concerning to:

1. The structure of the judicial system which is flawed regarding to the appointment of judges and the supreme court by the president on the proposal of the parliament. Of course, this term relates to politicization of the judiciary and if Albania has not made efforts in this direction means that the Albanian political class this important pillar joins it to her interests.

2. Another addressed issue is the complete immunity of judges, prescribed legally and this hinders the investigation of corruption cases, making not mistaken the perception that powerful people are not prosecuted. A case to be mentioned is the charges against former defense minister, which were interrupted because of the immunity. ${ }^{13}$

\footnotetext{
${ }^{9}$ http://www.legjislacioni.gov.al/sites/default/files/218-2009.pdf

10 http://www.legjislacioni.gov.al/sites/default/files/218-2010.pdf

${ }^{11}$ ec.europa.eu/enlargement.al/rapport_2003

${ }^{12}$ ec.europa.eu/enlargement.al/rapport_2006

${ }^{13}$ ec.europa.eu/enlargement.al/rapport_2010
} 
Although the year of 2011 will bring the adoption of the strategy for judicial reform, the problems will remain the same as the laws that want three fifths of votes are still pending. A moderate progress will be achieved in 2012 with the approval of the Law on Administrative Court and the Law on Advocacy ${ }^{14}$. A step towards impartiality was achieved with the law of the transfer of the judges based on merit. Progress will be also achieved against corruption in the judiciary through the adoption of the constitutional amendment, limiting the immunity of judges which meant fairway investigation, although 2013 would not mark any progress in the implementation of this law. Other changes affected the civil and criminal code with the purpose of approximation with European Legislation, but constitutional changes concerning the definitions independence, impartiality, efficiency still define the judicial reform as an unsolved problem.

\section{The Fight Against Corruption - Untapped Obligation}

Corruption is a major problem that has accompanied the assessment of the European Commission. In 2003, emphasis will be put to very small number of executions of decisions taken while in 2004 we ranked Albania will place 92 of 132 countries surveyed in the review for indicators of corruption ${ }^{15}$. Even though this year will be adopted the law on the declaration and control of the assets of public officials, the standing problem is notthe legislation but its implementation. Although Albania in 2005 took several steps such as signing the convention against corruption, anti-mafia package and increasing the number of officials who are under investigation. Just the evidence of criminal proceedings against corrupted prosecutors is indicative of the level of corruption. 2006 will bring a government initiative to waive the immunity of deputies in order to investigate into the cases of corruption that not only will not be approved in parliament but would bring strong debates. If we refer to the 2007 progress report thenn the few achievements of the Albanian government to develop a National Anti - Corruption 2004-2007, two considerable problems will be addressed as worries :

1. immunity of deputies

2. lack of a law that parties make public their assets ${ }^{16}$

These two problems will also be in 2008 and are referred to fact that Albania is part of the Group of States against Corruption of the Council of Europe ( GRECO ) which contains 13 recommendations and just only these two have not been met and this without any problem leads Albanian areas of policymaking. Regarding the legal side, it is worth mentioning the adoption in October 2008 of the multisectoral anti-corruption strategy and the use of electronic systems in taxes was trying to reduce the opportunity for corruption but a driving as it will open the debate on the smuggling of weapons and would bring to the firing of defense minister and undoubtedly will again give an estimate of " serious corruption problem "17 assessment that would come in 2009, but well as the problems identified will put emphasis on punishment at high levels. And obviously lacks the institutional framework here. The year 2011 will mark a breakthrough in strengthening the legal framework regarding the financing of political parties and to be evaluated is the initiative of some MPs to sign a declaration. Having entered 2013 with evaluation by the committee meeting the recommendations of GRECO initiative this year will also mark another achievement: the doubling of convictions in court, but the estimate for corruption remains a serious problem and unrealized criterion.

\section{Regional Cooperation - A Priority Issue with a Positive Evaluation}

Albania will have a uniform positive assessment in terms of relations and regional cooperation . Regarding international relations, Albania will become a member of OSCE in 1991 which will open its office in Albania in 1997, and since 1995 is a member of the Council of Europe and in 2000 will become a member of WTO. In 2007 , Albania will become a member with full rights in the Barcelona process and international cooperation will culminate in 2009 as a member of NATO . ${ }^{18}$ Regarding regional cooperation will focus on commercial field with the signing of the free trade agreement with all the countries of the region in 2004 . Regarding bilateral relations in the Balkans is worth mentioning that the period under study will have a positive evaluation without disregarding the fact that the entity Balkans will affect these relationships by providing cooling moments between neighbors. In a chronological order we can assume 2003 tense relations with the

\footnotetext{
${ }^{14}$ ec.europa.eu/enlargement.al/rapport_2012

${ }^{15}$ ec.europa.eu/enlargement.al/rapport_2004

${ }^{16}$ ec.europa.eu/enlargement.al/rapport_2007

${ }^{17}$ ec.europa.eu/enlargement.al/rapport_2008

${ }^{18}$ www.mie.gov.al
} 
Former Yugoslav Republic of Macedonia because of incidents occurring at the border. Yes, this year will mark the restoration of full diplomatic relations with Serbia and good neighborly relations with other countries will also continue in the coming years where Albania will be among the first Balkan country in 2006 will recognize Montenegrin 19independence which will follow the opening in 2007 of the Albanian embassy in Podgorica and the establishment of a border before it in the western Balkans . Relations with the former Yugoslav Republic of Macedonia will mark a positive step in 2008 with the conclusion of a free visa regime and border cooperation. Although 2008 will mark the relationship Albania - a certain cooling Serbia over Kosovo in 2010 will result in a meeting of Albanian foreign minister in Belgrade which will be followed in October 2012 with the visit of Serbian foreign minister Tirana. Although nationalist rhetoric would include part of 2013 the Albanian political factor that does not influence the relationship between good neighborliness Conclusions ${ }^{20}$

\section{Conclusion}

Treated with the above terms in relation to one of the key priorities for European Union membership in political criteria, focusing on 10 years of parliamentary life in the judiciary, public administration and regional cooperation issues can conclude as follows parliamentary life in Albania in the period 2003-2013 will focus on these areas during a 10-year period where we will come to Albania held parliamentary elections three times will be evaluated by the international community as peaceful transition of power from one political force to another.

International standards have increased in terms of electoral lists processes, tools of identification. But parliamentary life will be characterized by political gridlock in 2006, 2009 and will culminate in 2011 that would become a serious obstacle for the fulfillment of a criterion unrealized electoral reform and will show the weakness of the political class for a counstractive dialogue. While progress made is focused on parliamentary work which from year to year will have achievements. Also growing has been the focus of Parliament in the case of European integration.

Galleries for 10 years will be assessed in little steps towards administrative reform. Progress of this package will have a common denominator administration politicized. For civil administration the key of the reform priority will receive a positive direction in 2013 with the adoption of the law on civil service but remains a long way in its implementation. But the European Commission problematic assessment will remain the judiciary and corruption scanning and proposed steps in this key can us to conclude that the reforms in the judiciary leaves to be desired. Not only the fact of a legislation that represents his issues with respect to structuring the system leaves room politicization and this not inadvertently by the political class when it comes to the appointment of judges procedures but also their immunity wears with an untouchable power is coming to the aid of this political class that justifies not only the problems of lack of the legal framework but also in the implementation of decisions neglect and corruption in this area. Tasks left by the commission each year will address three words system efficiency and transparency independence does fulfill these obligations, is the obligation for a positive assessment. Attached to the problems of corruption in the judiciary remains part of the Albanian society even at high levels despite legal initiatives undertaken considerable problems finding was recorded in two progress reports were senior officials immunity and disclosure of political party finances turn this area obviously problematic regional cooperation and good neighborly relations form a substantial part of the integration process of Albania in EU by reference to international obligations and regional Co-operation, we can say that 10 years of progress reports listed in Albanian give a positive note in this priority .

\section{References}

ec.europa.eu/enlargement.al/rapport_2003 ec.europa.eu/enlargement.al/rapport_2004 ec.europa.eu/enlargement.al/rapport_2005 ec.europa.eu/enlargement.al/rapport_2006 ec.europa.eu/enlargement.al/rapport_2007 ec.europa.eu/enlargement.al/rapport_2008 ec.europa.eu/enlargement.al/rapport_2009 ec.europa.eu/enlargement.al/rapport_2010

\footnotetext{
${ }^{19} \mathrm{http}: / / w w w . l e g j i s / a c i o n i . g o v . a l / s i t e s / d e f a u l t / f i l e s / 2006$
}

${ }^{20}$ ec.europa.eu/enlargement.al/rapport_2013 
ec.europa.eu/enlargement.al/rapport_2011

ec.europa.eu/enlargement.al/rapport_2012 ec.europa.eu/enlargement.al/rapport_2013

http://www.legjislacioni.gov.al/sites/default/files/

www.mie.gov.al 